УДК $331.52+631.147$

DOI: $10.15673 /$ fie.v12i4.1906

\author{
Нікішина О.В \\ доктор економічних наук, старший науковий співробітник \\ завідувач відділу ринкових механізмів та структур \\ E-mail: ksenkych@gmail.com \\ ORCID ID: 0000-0002-7172-3551 \\ Тараканов М.Л. \\ кандидат економічних наук, старший науковий співробітник \\ відділ ринкових механізмів та структур \\ Інститут проблем ринку та економіко-екологічних досліджень НАН України \\ Французький бульвар, 29, м. Одеса, Україна, 65044 \\ E-mail: tarakanovnikolajleonidovic@gmail.com \\ ORCID ID: 0000-0002-3827-237
}

\title{
ТЕОРЕТИКО-МЕТОДИЧНІ ЗАСАДИ ЛОГІСТИЧНИХ «РОЗРИВІВ» У ЛАНЦЮГАХ ТОВАРНИХ РИНКІВ*
}

Стаття присвячена обґрунтуванню теоретико-методичного забезпечення для ідентифікації та діагностики логістичних «розривів» потокових процесів у ланцюгах товарних ринків на засадах відтворювального підходу та GAP-аналізу. Доведено доцільність використання спеціальних категорій для диференціації проблемних областей товароруху за рівнями їх прояву в матеріалопровідній системі ринку, а саме: ланцюг - ланка - логістична операція. Запропоновано авторське визначення категорії «логістичний «розрив» з акцентом на причинах виникнення «розривів» потокових процесів товарного ринку у внутрішньому та зовнішньому вимірі. Розроблено розширену класифікацію логістичних «розривів» у ринкових ланцюгах за 9 ознаками, визначено їх природу та практичні прояви в ланцюгах агропродовольчих ринків України. Запропоновано методичний підхід до діагностики GAP, що передбачає ранжування «розривів» параметрів потокових процесів товарного ринку за ступенем їх значимості для ефективного функціонування ринкових ланцюгів та визначення граничних величин «розривів» за допомогою методу експертних оцінок.

Ключові слова: логістичний «розрив», ланцюг товарного ринку, ланка, потокові процеси, параметри, діагностика логістичних «розривів».

This work is licensed under a Creative Commons Attribution 4.0 International License http://creativecommons.org/licenses/by/4.0/

Постановка проблеми та їі зв'язок з важливими науковими та практичними завданнями. Завдання подолання логістичних розривів (далі - ЛР) потокових процесів стратегічних ринків України $€$ вкрай актуальним у сучасних умовах посилення впливу логістики на ефективність функціонування товарних ринків. Логістичний підхід орієнтований на управління наскрізним матеріальним потоком і відповідними йому інформаційним і фінансовими потоками, однак на практиці постійно виникають різноманітні «розриви» даних потокових процесів, які мають різну природу, глибину, ступінь впливу на ефективність логістичних ланцюгів товарних ринків (далі - ЛЛТР). У контексті ринкової теорії проблематика ЛР залишається недостатньо дослідженою.

Формування теоретико-методологічної бази для ідентифікації та діагностики ЛР потокових процесів товарних ринків сформує наукове підгрунтя для розробки механізмів і заходів подолання таких «розривів» 3 урахуванням їх відмінностей та форм прояву у різних типах ЛЛТР. В основу теоретикометодичних засад ЛР у ринкових ланцюгах доцільно покласти відтворювальний підхід та GAP-аналіз, який $\epsilon$ одним із методів стратегічного аналізу «розривів» між поточним і бажаним станом економічних систем різних рівнів. На наш погляд, застосування GAPаналізу в ринковій логістиці може стати ефективним інструментом діагностики та управління ЛЛТР, аналітичним підгрунтям для розробки адаптивних механізмів і заходів нівелювання «розривів» потокових процесів ринку в сучасних умовах економічної нестабільності.

Аналіз останніх публікацій по проблемі. Різним аспектам теорії логістики, зокрема проблемним питанням товароруху, присвячено праці Бринцева О.М. [1, 2], О. П. Величко, О.Д. Вірозуба [3], О. Б. Гірної, Г.М. Грейза [4], Л.М. Гурч, Є. В. Крикавського, Т.I. Курант [5], Т.О. Осташко [6], Ю.В. Пономарьової, О.М. Сумця та інших науковців. Природу деформацій та диспропорцій в економічних

\footnotetext{
* Публікацію підготовлено в межах виконання НДР «Формування ефективної логістики товарних ринків» (№ державної реєстрації 0119U000227).
} 
системах досліджували учені Б.О.Плишевський [7] та Л.В. Шинкарук [8]. Водночас сучасний стан розвитку макрологістичних систем, зокрема ЛЛТР, вимагає поповнення понятійно-категоріального апарату, зокрема, визначення терміну «розрив» у ринковологістичному вимірі, доцільності його застосування в логістиці товарного ринку. Актуальність даного дослідження посилюється відмінностями в передумовах та заходах нівелювання ЛР різних видів у ринкових ланцюгах різних типів, що обумовлює необхідність розробки відповідного теоретико-методичного забезпечення.

Формулювання цілей дослідження. Мета статті - розробка теоретико-методичного базису для визначення та діагностики логістичних «розривів» потокових процесів у ЛЛТР на засадах відтворювального підходу та GAP-аналізу, як підгрунтя для обгрунтування механізмів і заходів нівелювання «розривів» 3 урахуванням їх специфіки та особливостей товарних ринків.

Виклад основних результатів та їх обгрунтування. Для досліджень проблемних областей товароруху в ринках учені застосовують низку економіч- них категорій, які, на наш погляд, доцільно розділити на дві групи (таблиця 1): (1) загальні терміни, притаманні будь-яким економічним системам; (2) спеціальні категорії, що характеризують особливості логістичних процесів товарного ринку.

Термін «деформація» визначає стійке відхилення фактичного від певного оптимального стану економічної системи в біг пригнічення процесу їі розвитку [7]. Категорію «диспропориія» учені визначають як певне відхилення від пропорцій та пропорційності, які, в свою чергу, характеризують частку чогось у цілому, або співвідношення одного процесу до іншого, гармонійність між компонентами [8, с.73]. Сутність економічних диспропорцій С.В. Мочерний розкриває як порушення необхідних співвідношень у розвитку окремих підрозділів, територіальних, галузевих, господарських комплексів. При цьому він виділяє часткові диспропорції, що мають локальний, тимчасовий характер, і загальні, пов'язані з порушеннями процесу відтворення в цілому та тривалим періодом дії [9, с.348]. Диспропорції постають джерелом дисбалансів.

Таблиця 1

Понятійно-категоріальний апарат сучасних досліджень проблемних областей товароруху в ринку

\begin{tabular}{|c|c|c|}
\hline Категорія & Сутність & Область прояву \\
\hline \multicolumn{3}{|c|}{ Загальні категорії } \\
\hline $\begin{array}{l}\text { 1. Деформація } \\
\text { [7] }\end{array}$ & $\begin{array}{l}\text { Стійке відхилення від певного оптимального стану в бік приг- } \\
\text { нічення процесу розвитку економіки - ії динаміки, викорис- } \\
\text { тання чинників зростання, пропорцій відтворення }\end{array}$ & Економічна система \\
\hline $\begin{array}{l}\text { 2. Диспропорція } \\
{[9, \text { с.348] }}\end{array}$ & $\begin{array}{l}\text { Порушення необхідних співвідношень у розвитку окремих під- } \\
\text { розділів, територіальних, галузевих, господарських (націона- } \\
\text { льних й світових рівнів) комплексів. }\end{array}$ & Економічна система \\
\hline $\begin{array}{l}\text { 3. Дисбаланс } \\
{[10]}\end{array}$ & $\begin{array}{l}\text { Порушення економічної рівноваги, збалансованості процесів, } \\
\text { потоків у компанії, регіоні, державі }\end{array}$ & Економічна система \\
\hline \multicolumn{3}{|c|}{ Спеціальні категорії } \\
\hline $\begin{array}{l}\text { 1. Логістичний } \\
\text { бар’єр }\end{array}$ & $\begin{array}{l}\text { Перешкоди на шляху потокових процесів в ринку, пов’язані зі } \\
\text { стандартними (зміна транспорту, перехід прав власності на } \\
\text { товар, виконання митних процедур та ін.) та нестандартними } \\
\text { процедурами (наприклад, неврегульованість митних операцій) } \\
\text { (aвт.) }\end{array}$ & $\begin{array}{l}\text { Логістичний ланцюг } \\
\text { товарного ринку }\end{array}$ \\
\hline 2. «Вузьке» місце & $\begin{array}{l}\text { Найгірші параметри логістичного обслуговування, які суттєво } \\
\text { знижують ефективність ланки ринкового ланцюга (авт.) }\end{array}$ & $\begin{array}{l}\text { Ланка ринкового лан- } \\
\text { цюга }\end{array}$ \\
\hline $\begin{array}{l}\text { 3. Точка логісти- } \\
\text { чних втрат }\end{array}$ & $\begin{array}{l}\text { Найгірші параметри обслуговування товароруху, які скорочу- } \\
\text { ють ефективність логістичної операції в складі ланки ринково- } \\
\text { го ланцюга (авт.) }\end{array}$ & $\begin{array}{l}\text { Логістична операція у } \\
\text { складі ланки ЛЛТР }\end{array}$ \\
\hline \multirow[t]{2}{*}{$\begin{array}{l}\text { 4. Логістичний } \\
\text { «розрив» } \\
\text { («gар») } \\
{[4,11]}\end{array}$} & $\begin{array}{l}\text { Невідповідність між поточними і бажаними характеристиками } \\
\text { логістичної системи. } \\
\text { Проміжок, створений між елементами системи, в результаті } \\
\text { обривання відносин між суб’єктами різних ланок логістичного } \\
\text { ланцюга по відповідному параметру. }\end{array}$ & Логістична система \\
\hline & $\begin{array}{l}\text { Розбіжність між фактичними й оптимальними (бажаними, но- } \\
\text { рмативними) значеннями параметрів потокових процесів в ри- } \\
\text { нку внаслідок порушення оптимальних співвідношень між } \\
\text { елементами ЛЛТР, послаблення (відсутності) зв'язків і взаємо- } \\
\text { дій між його ланками, що не забезпечує розширене відтворен- } \\
\text { ня товароруху та оптимізацію загальної доданої вартості в ри- } \\
\text { нку (авт.) }\end{array}$ & $\begin{array}{l}\text { Ланки ланцюга } \\
\text { Логістичний ланцюг } \\
\text { товарного ринку та } \\
\text { його зовнішнє сере- } \\
\text { довище }\end{array}$ \\
\hline
\end{tabular}

*Розроблено авторами з використанням джерел $[4,7,9,10,11]$ 
Відповідно до положень загальної теорії рівноваги, пропорційність виступає умовою досягнення повної і часткової рівноваги та нерівноважних станів; причинами двох останніх $є$ диспропорції, які генерують дисбаланси [8, с.72]. Енциклопедичні ресурси визначають категорію «дисбаланс» як порушення економічної рівноваги, збалансованості певних процесів і потоків на мікро-, мезо- та макрорівні, розрізняючи внутрішні і зовнішні дисбаланси [10]. Проф. Л.В. Шинкарук запропонувала власну класифікацію дисбалансів за ознаками глибини та рівнями економіки. Так, за глибиною науковець виділила поверхневі та глибинні дисбаланси, за рівнями економіки - загальноекономічні, міжгалузеві, внутрішньогалузеві та територіальні [8, с.73].

Розглянуті загальні категорії (з певною адаптацією) використовуються в теорії логістики для характеристики проблемних областей товароруху в логістичних системах різних рівнів. У ході проведених досліджень [12] обгрунтовано доцільність виокремлення спеціальних категорій «логістичний бар'єр», «вузьке місце» та «точка логістичних втрат» (див. табл. 1) для диференціації проблемних областей товароруху за рівнями їх прояву в матеріалопровідній системі ринку: ланцюг - ланка - логістична операція.

На думку проф. Бринцева О.М., будь-який поділ товарного потоку є фрагментом або бар'єром, який необхідно подолати. Учений розробляє класифікацію логістичних бар'єрів, ідентифікуючи фрагментарні бар'єри 1 і 2 рівнів, каскадні, змішані та інші бар'єри. Він доводить, що в економічних системах найбільш повно логістичні процеси описують фрагментарні бар'єри 2-го рівня, які представляють собою перетин трьох потоків (матеріального, інформаційного й фінансового) в місці фрагменту [1, с.67-68].

У ринковому вимірі термін «логістичний бар'єр» ми пропонуємо розглядати як перешкоди на шляху руху матеріального і відповідного йому інформаційного й фінансового потоків, обумовлені певними змінами умов їх переміщення в географічних межах ринку. Це стосується, наприклад, зміни видів транспорту, здійснення технологічних та фінансових операцій, переходу прав власності на товар тощо. Виникає ситуація 3 фрагментацією логістичних потоків, коли попередній стан потоку відрізняється від наступного. Як правило, логістичні бар'єри мають два аспекти прояву: (1) бар'єри носять «нормативний» характер і потребують витрат на їх проходження за стандартними процедурами (наприклад, перетин кордону); (2) виникає потреба у додаткових витратах, пов'язаних зі складнощами їх подолання (наприклад, неврегульованість митних процедур).

Термін «вузьке місие» спочатку використовувався у виробничій сфері, визначаючи недостатність компонентів у ланцюгу технологічного процесу, яка нівелювалась застосуванням організаційно-технічних заходів. Нині даний термін застосовується в логістиці та характеризує найгірші параметри логістичного обслуговування, які суттєво знижують ефективність ланки ринкового ланцюга (див. табл. 1). Категорія «точка логістичних втрат» має близьке 3 попереднім терміном значення, але відрізняється від нього областю прояву - логістичною операцією, як найменшою структурною складовою, у складі ланки ланцюга.

Термін «розрив» був інтегрований в логістику із методики GAP-аналізу, який представляє собою один із різновидів стратегічного аналізу, що вивчає невідповідність між поточним і бажаним станом підприємства, причини їі виникнення та шляхи подолання. В теорії GAP-аналізу учені трактують «розрив» як невідповідність реальних (поточних) можливостей системи бажаному (потенційному) рівню ефективності іï функціонування [11]. На наш погляд, дане визначення притаманне і логістичним системам. Деякі учені визначають сутність логістичного «розриву» як проміжок, створений між елементами системи, в результаті обривання відносин між різними ланками ланцюга по відповідному параметру [4, с.161], акцентуючи увагу на оптимізації взаємодій між учасниками логістичних процесів на засадах узгодження їх різновекторних інтересів.

Проведене дослідження сутності понятійного апарату (див. табл. 1) дозволило дійти висновку, згідно 3 яким: (1) різним категоріям відповідають різні області прояву проблемних аспектів товароруху в ринку; (2) за змістом дані категорії недостатньо чітко розмежовуються один від одного, що пояснюється відсутністю уявлення про глибину, межі та особливості проявів проблемних ситуацій у залежності від типу товарного ринку, специфіки його процесів відтворення та міжсуб'єктних взаємодій, якості інституційного забезпечення, цільових орієнтирів розвитку, узгоджених із діючою державною політикою, тощо.

На думку авторів, найбільш повно розкриває сутність і природу проблемних областей товароруху в ринку категорія логістичний «розрив». Даний висновок обумовлений низкою причин, зокрема: (1) різними областями прояву «розривів» - від ланки ланцюга певного типу до їх сукупності у межах товарного ринку; (2) більш масштабним негативним впливом на ефективність функціонування ЛЛТР та досягнення їх цільових орієнтирів; (3) чітко визначеною глибиною прояву «розривів» - це відсутність логістичних відносин за певним параметром, що означає їх підміну іншими, не логістичними інструментами обслуговування товароруху.

На підставі проведеного дослідження запропоновано авторське визначення категорії логістичний «розрив», а саме: розбіжність між фактичними й оптимальними (бажаними, нормативними) значеннями параметрів потокових процесів в ринку внаслідок порушення оптимальних співвідношень між елементами ЛЛТР, послаблення (відсутності) зв'язків і взаємодій між його ланками, що не забезпечує розширене відтворення товароруху та оптимізацію загальної ринкової доданої вартості. Дане визначення базується на теорії GAP-аналізу та відтворювальному підході, акцентуючи увагу на причинах виникнення «розривів» та їх деструктивному впливі на досягнення головної відтворювальної мети ЛЛТР. Відмінністю авторського визначення категорії також $є$ розширена область прояву логістичних «розривів», яка включає 
не тільки внутрішнє, а й зовнішнє середовище досліджуваного (релевантного) ринкового ланцюга, його взаємодію із іншими ланцюгами (корпоративними, кооперативними, державно-приватними) у географіч- них межах товарного ринку, із глобальними ланцюгами вартості, природним середовищем тощо. Тобто маємо дві площини генерації ЛР - внутрішню і зовнішню, що графічно відображено на рис. 1.

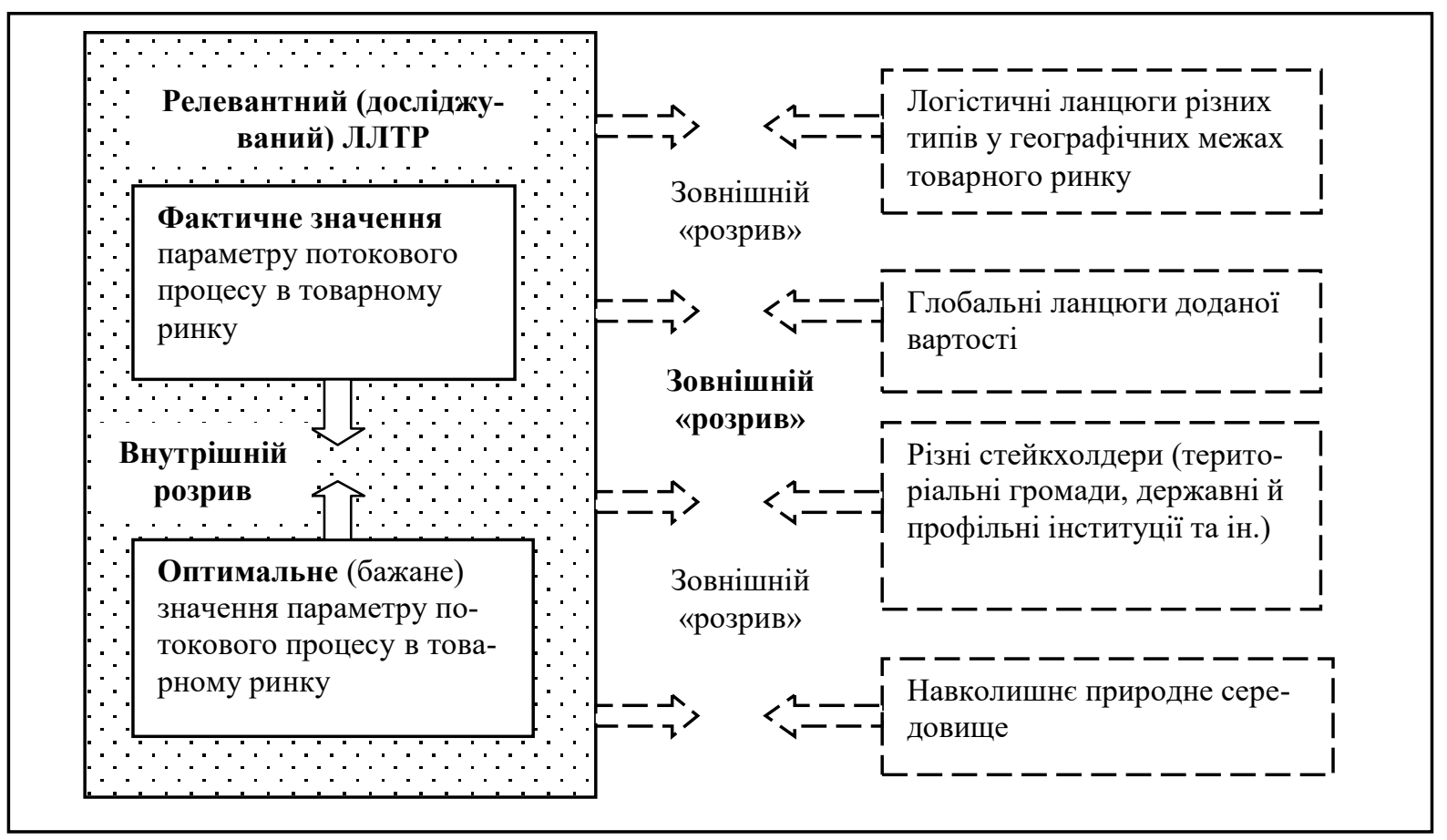

Рис. 1. Місця виникнення внутрішніх і зовнішніх логістичних «розривів» потокових процесів товарного ринку*

*авторська розробка

В існуючих дослідженнях «розриви» розглядаються у межах логістичної системи, відтак, мають тільки внутрішній вимір. Авторський підхід передбачає розширення наукового поля дослідження за рахунок діагностики зовнішніх розривів, що виникають у ході складних взаємодій релевантного ЛЛТР із іншими ланцюгами та різноманітними стейкхолдерами (див. рис. 1). Оскільки розбудова окремих ланок логістичного ланцюга здійснюється на локальних територіях, його суб'єкти взаємодіють із місцевими органами влади, державними і профільними інституціями, а також територіальними громадами. У процесі такої взаємодії можуть виникати суперечності щодо земельних відносин, інституційного забезпечення, перерозподілу доходів та ін., які впливають на ефективність релевантного ЛЛТР. Екологічні «розриви» виникають у процесі взаємодії ринкових ланцюгів із навколишнім природним середовищем і характеризують стан екологічної безпеки системи для суспільства в цілому.

У цілому ідентифікація внутрішніх і зовнішніх «розривів» потокових процесів ринку значно розширює аналітичне поле для їх системної діагностики, визначення глибинних причин та заходів подолання. Слід зазначити, що внутрішні ЛР також мають подвійну природу, оскільки виникають як у межах певної ланки ринкового ланцюга (внутрішньоланкові), так і між різними його ланками (міжланкові). На практиці в ланцюгах агропродовольчих ринків Украї- ни базовим «розривом» є необ'єктивний перерозподіл доданої вартості між суб'єктами різних ланок, який генерує низку структурних диспропорцій у процесах відтворення та знижує ефективність ЛЛТР. Відтак, внутрішні й зовнішні ЛР мають багатокомпоненту структуру, яку, безперечно, слід врахувати в ході розробки класифікації ЛР потокових процесів ринку.

Питання класифікації «розривів» в теорії логістики залишається малодослідженим. У класичній теорії GAP-аналізу учені виділяють 6 категорій розривів [11]: (1) ринкові; (2) в якості продукції та обслуговуванні; (3) організаційні; (4) керівництво бізнесом; (5) бізнес-процеси; (6) інформаційні технології. Однак така класифікація ЛР не відображає сутність проблемних аспектів товароруху в ринку. Базуючись на результатах попередніх досліджень [5, 7, 11], авторами розроблену власну класифікацію «розривів» у ринково-логістичному вимірі за 9-ти ознаками (таблиця 2).

За місцем виникнення у релевантному ЛЛТР можна виділити внутрішні і зовнішні логістичні «розриви» (див. рис. 1), які, в свою чергу, поділяються на певні підвиди. У складі міжланцюгових «розривів» ми пропонуємо виокремити послідовні та паралельні «розриви» (див. табл. 2). Послідовні ЛР виникають у взаємодіях між ланцюгами, які доповнюють один одного в ході здійснення ринкових процесів відтворення. 
Класифікація логістичних «розривів» потокових процесів товарного ринку*

\begin{tabular}{|c|c|}
\hline Ознака & Види логістичних «розривів» \\
\hline $\begin{array}{l}1.3 а \text { місцем виникнення у } \\
\text { релевантному ЛЛТР }\end{array}$ & $\begin{array}{l}\text { 1. Внутрішні: } \\
\text { 1.1. Внутрішньоланкові } \\
\text { 1.2. Міжланкові } \\
\text { 2. Зовнішні: } \\
\text { 2.1. Міжланцюгові (послідовні та паралельні) } \\
\text { 2.2. Між релевантним ЛЛТР і різними стейкхолдерами } \\
\text { 2.3. Між релевантним ЛЛТР і навколишнім природнім середовищем }\end{array}$ \\
\hline $\begin{array}{l}\text { 2.3а видами потокових про- } \\
\text { цесів товарного ринку }\end{array}$ & $\begin{array}{l}\text { 1. Прості (однопотокові): } \\
\text { 1.1. ЛР матеріального потоку } \\
\text { 1.2. ЛР інформаційного потоку } \\
\text { 1.3. ЛР фінансового потоку } \\
\text { 2. Комбіновані: } \\
\text { 2.1.ЛР матеріального, інформаційного та фінансового потоків } \\
\text { 2.2. ЛР матеріального та фінансового / інформаційного потоків } \\
\text { 2.3. ЛР інформаційного та фінансового потоків }\end{array}$ \\
\hline $\begin{array}{l}\text { 3.3а глибиною впливу на фу- } \\
\text { нкціонування ЛЛТР }\end{array}$ & $\begin{array}{l}\text { 1. Поверхневі (локальні) } \\
\text { 2. Суттєві } \\
\text { 3. Глибинні (системні) } \\
\end{array}$ \\
\hline 4.3а причинами виникнення & $\begin{array}{l}\text { 1. Природні } \\
\text { 2. Штучні }\end{array}$ \\
\hline $\begin{array}{l}\text { 5. За структурною будовою } \\
\text { ланциюга }\end{array}$ & $\begin{array}{l}\text { 1. ЛР у складі незавершеного логістичного ланцюга } \\
\text { 2. ЛР у складі зайвих ланок логістичного ланцюга }\end{array}$ \\
\hline $\begin{array}{l}\text { 6. За формами зв'язків міжс } \\
\text { ланками ЛЛТР }\end{array}$ & $\begin{array}{l}\text { 1. ЛР двосторонніх зв'язків між суміжними ланками ЛЛТР } \\
\text { 2. ЛР централізованих зв’язків між провідною та іншими ланками ЛЛТР } \\
\text { 3. ЛР зв'язків між ланцюгами корпоративного типу та ін. типами в товар- } \\
\text { ному ринку }\end{array}$ \\
\hline $\begin{array}{l}\text { 7.3а співвідношен-ням по- } \\
\text { питу й пропозиції }\end{array}$ & $\begin{array}{l}\text { 1. Міжланкові ЛР в умовах ринкової рівноваги } \\
\text { 2. Міжланкові ЛР в умовах перевищення попиту над пропозицією } \\
\text { 3. Міжланкові ЛР в умовах перевищення пропозиції над попитом }\end{array}$ \\
\hline $\begin{array}{l}\text { 8. За географічними межами } \\
\text { ЛЛТР }\end{array}$ & $\begin{array}{l}\text { 1. ЛР в ланцюгах локальних товарних ринків } \\
\text { 2. ЛР в ланцюгах регіональних товарних ринків } \\
\text { 3. ЛР в ланцюгах державних товарних ринків } \\
\text { 4. ЛР в ланцюгах глобальних товарних ринків }\end{array}$ \\
\hline $\begin{array}{l}\text { 9.3а адаптацією ЛЛТР до } \\
\text { заходів державної підтрим- } \\
\text { ки товароруху }\end{array}$ & $\begin{array}{l}\text { 1. ЛР як реакція ланцюга на державну підтримку виробництва товарів } 3 \\
\text { високою доданою вартістю } \\
\text { 2. ЛР як реакція ланцюга на державну підтримку експорту товарів } 3 \text { висо- } \\
\text { кою доданою вартістю } \\
\text { 3. ЛР як реакція ланцюга на державну політику імпортозаміщення }\end{array}$ \\
\hline
\end{tabular}

*Авторська розробка

Послідовні «розриви» через функцію розподілу можуть виникати між корпоративними, кооперативними й державно-приватними ланцюгами, між національними й глобальними ланцюгами вартості, а також між ланцюгами локальних / регіональних товарних ринків, порушуючи важливий принцип ефективної логістики - просторово-часового збалансування наскрізних матеріального, фінансового й інформаційного потоків. Паралельні ЛР виникають одночасно в ринкових ланцюгах різних типів і характеризують їх відтворювальні можливості та нерівномірні умови розвитку, проявом яких $є$ різний доступ великих, середніх і малих учасників товароруху до логістичних послуг, монополізація ланок ЛЛТР крупними логістичними провайдерами та ін.

За видами потокових процесів товарного ри- нку можна виділити дві групи ЛР (див. табл. 2): (1) прості або однопотокові, які локалізуються в межах одного потоку - матеріального, фінансового або інформаційного; (2) комбіновані, що виникають одночасно в трьох або двох потоках. На практиці найбільш поширеними є комбіновані ЛР, оскільки «розрив» базового матеріального потоку супроводжується, як правило, фінансовими втратами учасників логістичного процесу та інформаційними «розривами». Проблема асиметричності інформації, коли більшим масивом достовірної інформації володіють найсильніші суб'єкти ринку, підсилює існуючі структурні й фінансові деформації ринкових процесів відтворення, цінову волатильність, генерує втрати доданої вартості найменш захищених суб'єктів, передусім дрібних товаровиробників, внаслідок прийняття невірних 
економічних рішень. У логістичних системах різних рівнів теж існують інформаційні «розриви» при взаємодії контрагентів-учасників, обумовлюючи необхідність розробки моделі виявлення різних типів даних «розривів» на проміжних етапах логістичного та інформаційного потоків [5, с. 100].

Графічно однопотокові та комбіновані ЛР зображено на рис. 2. Проф. Бринцев О.М. точку перетину трьох потокових процесів визначає як «біфуркацію в місці перетину потоків» та доводить, що 3 точки зору теорії ймовірності настання проблемної події в даній точці буде вищою, ніж у місці простого «розриву» $[1$, с.68]. Оскільки біфуркація передбачає якісну перебудову певного об’єкту при зміні умов, від яких він залежить, можна стверджувати, що в точці генерації комбінованого «розриву» відбувається трансформація певних параметрів логістичних потоків та напрямів їх руху в ЛЛТР, що може змінити його структурну будову. Наприклад, внаслідок необ'єктивного співвідношення ціна/якість елеваторних послуг більшість дрібних виробників відмовилися від послуг монопольних елеваторів і стали зберігати зерно на власних складах, використовуючи його для внутрішнього споживання. Відтак, у межах аграрної ланки індивідуального сектору ринку сформувався власний мікрологістичний ланцюг: насіння - зерно - зберігання - фуражне споживання [13, с.24]. ЛР між ланками виробництва та зберігання й доробки зерна обумовив зворотній рух частини матеріального потоку (близько 35 \%) до аграрної ланки, який супроводжувався зниженням якісних параметрів культур та фінансовими втратами індивідуальних виробників. У цьому випадку комбінований ЛР змінив структуру ланцюга зернового ринку та параметри логістичних потоків, знизив ефективність функціонування аграрної ланки та ланцюга в цілому. Загалом сучасна будова ланцюга зернового ринку не $є$ оптимальною 3 точки зору становлення відтворювальної логістики та забезпечення розширеного товароруху в ринку.

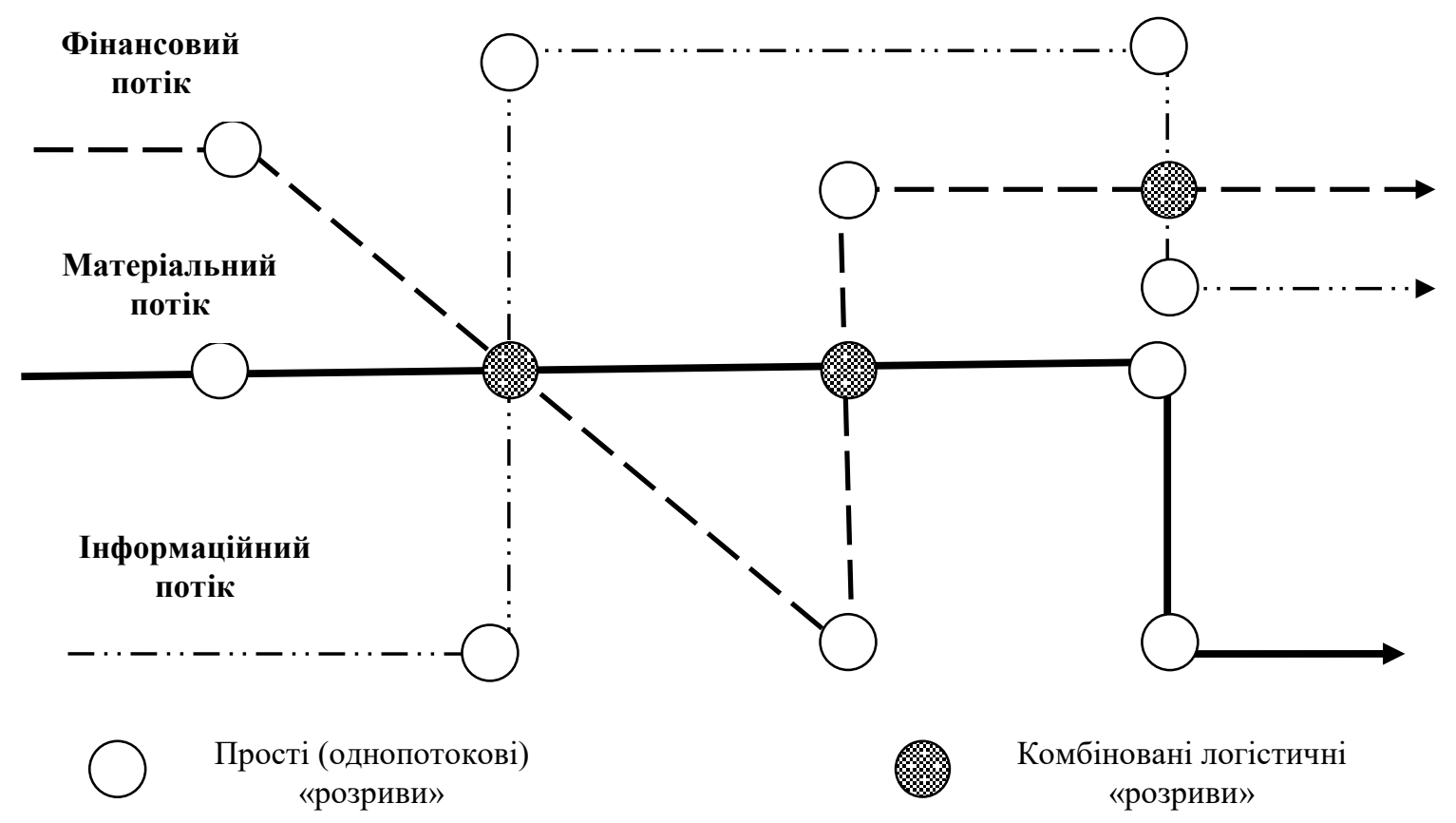

Рис. 2. Прості та комбіновані логістичні «розриви» в ЛЛТР* " розроблено авторами на основі джерела [1, с.68]

За глибиною впливу на функціонування ринкових ланцюгів логістичні «розриви» доцільно класифікувати на поверхневі, суттєві та глибинні (див. табл. 2). Поверхневі ЛР мають короткостроковий характер і чинять незначний локальний вплив на параметри товароруху певних ланок ланцюга. Суmmєвi «розриви» потокових процесів носять середньостроковий характер і генерують істотні порушення у взаємодіях певних ланок ЛЛТР, що супроводжуються фінансовими втратами певних груп учасників логістичних процесів. Вищеописаний приклад ЛР між індивідуальним сектором аграрної ланки й наступною ланкою зберігання й доробки зерна може бути віднесений до категорії суттєвих «розривів», що істотно знижують ефективність аграрної ланки. Глибинні ЛР мають довгостроковий характер і здійснюють системний деструктивний вплив на ключові параметри матеріалопровідного ланцюга, генеруючи низку втрат для суб'єктів ринку, держави та населення. Прикладом глибинного ЛР на зерновому ринку України $є$ домінуючий експортний напрям руху зерна (63-68 \% від валового збору), який, в свою чергу, генерує низку дисбалансів на всіх етапах процесу відтворення, i може привести до повного занепаду переробної ланки, трансформації ринкового ланцюга в нерозвинений та істотного зниження його відтворювальної спроможності [13, с.27]. 
За причинами виникнення в ринкових ланцюгах можна виділити природні та штучні ЛР (див. табл. 2). Природні «розриви» пов'язані зі стандартними проблемними областями товароруху та обумовлені впливом кліматичного (наприклад, сезонність агровиробництва, стислі терміни дозрівання й реалізації продукції) та технологічного (оновлення технологій) чинників, переходом права власності на товар у ході його міжланкового переміщення, специфікою потокових процесів певного товарного ринку. Так, матеріальний потік аграрного ринку має подвійну природу небіологічну й біологічну, при цьому остання обумовлює неминучість біологічних втрат, які відбуваються внаслідок протікання в продукції різних біохімічних процесів. Природний характер мають такі втрати матеріального потоку, як неврахований розпил при переміщенні зерна, картоплі та овочів, втрати вологи при зберіганні плодово-овочевої продукції та ін. [3, c.199]. Штучні «розриви» обумовлені високими бар'єрами доступу на ринок, монополізацією товарних ринків, недосконалістю інституційного забезпечення паритетних відносин між учасниками логістичного процесу, що, в свою чергу, супроводжується необ'єктивним міжланковим перерозподілом доданої вартості, інформаційною асиметрією та зниженням ефективності ринкового ланцюга. До групи штучних ЛР доцільно віднести також втрати, що виникають внаслідок нераціональної організації зберігання продукції, порушення режимів і правил, нецільового використання товарного потоку, неефективного управління його рухом у ринку та недостатньої кваліфікації управлінського персоналу [3, с.200].

За структурною будовою ринкового логістичного ланцюга запропоновано виділити два типи ЛР, які продукують певні розбіжності між фактичними $\mathrm{i}$ бажаними параметрами потокових процесів (див. табл. 2). Перший тип «розривів» виникає у складі незавершеного ЛЛТР, в якому відсутність (нерозвиненість) певних ланок, передусім розподілу й реалізації продукції, не дозволяє забезпечити розширене відтворення товароруху в ринку. Другий тип «розривів» виникає внаслідок існування зайвих ланок ЛЛТР (зокрема, посередницьких), обумовлюючи зростання логістичних витрат за одночасного погіршення якісних характеристик товароруху. Логістичні «розриви» такого типу здійснюють значний деструктивний вплив на відтворювальний розвиток плодово-ягідного ринку України. У структурі даного ланцюга функціонують декілька посередницьких ланок, через які реалізується близько 70 \% продукції, водночас відсутній логістичний центр (оптовий ринок сільгосппродукції), який повинен виконувати зв'язуючу функцію між дрібними товаровиробниками й оптовими покупцями на паритетних засадах. Досягнення цільових орієнтирів відтворювальної логістики передбачає оптимізацію структурної будови ЛЛТР.

За формами зв'язків між ланками ЛЛТР можна виокремити «розриви» трьох типів (див. табл. 2). Проявом ЛР двосторонніх зв'язків між суміжними ланками ланцюга $€$ порушення базового принципу паритетних взаємодій, реалізація економічних інте- ресів одного партнера за рахунок іншого, короткочасний й нестабільний характер відносин, суперечливість інформації щодо вибору партнерів тощо. Ознакою ЛР централізованих зв'язків між провідною (виробничою, розподільчою та ін.) та іншими ланками ланцюга $\epsilon$ неможливість ефективного управління провідною ланкою потоковими процесами в ринку, відсутність інструментів міжланкової синхронізації товарно-фінансових потоків за обсягами, в просторово-часовому вимірі, тощо. Ринкові ланцюги корпоративного типу $є$ найбільш ефективними, оскільки в них реалізовано базовий принцип управління наскрізним матеріальним і відповідним йому фінансовим й інформаційним потоком. Водночас такі ланцюги, акумулюючи значну частину ринкової доданої вартості за рахунок дискримінаційних умов взаємодії 3 малими й середніми суб'єктами, посилюють їх логістичну «відторгненість», існуючі відтворювальні дисбаланси ринку, що не відповідає економічним інтересами держави та суспільства в цілому. ЛР зв'язків між ланцюгами корпоративного та інших типів (кооперативного, державного) досить гостро проявляються в агропродовольчих ринках $[12,13]$.

За співвідношенням попиту й пропозиції товарів можна виділити три типи міжланкових «розривів» у ринкових логістичних ланцюгах (див. табл. 2). Проявом ЛР в умовах ринкової рівноваги може бути відсутність мобільних ланок (наприклад, мобільних складів) ринкових ланцюгів, спроможних швидко переорієнтуватися на короткострокові області незадоволеного споживчого попиту. Головною причиною міжланкових ЛР в умовах перевищення попиту над пропозицією є нерозвиненість логістичної інфраструктури ринку, зокрема, логістичних провайдерів, спроможних централізовано задовольняти динамічний споживчий попит. Ознаками ЛР в умовах перевищення пропозиції над попитом товару є невідповідність параметрів ланок ЛЛТР споживчим вимогам локального попиту, відсутність ланок складської логістики, спроможних регулювати обсяги, номенклатуру та терміни постачань.

Слід відзначити, що поділ ЛР за 5, 6 та 7-ю класифікаційними ознаками (див. табл. 2) стосується, передусім, «розривів» між ланками ланцюга, що ототожнюють етапи ринкового процесу відтворення (виробництво, розподіл, обмін та споживання) та характеризують порушення пропорційності відтворювального розвитку певного ЛЛТР. Дане твердження є свідченням практичної значимості багатоаспектної класифікації міжланкових «розривів» і їх діагностики за допомогою структурних індикаторів за головними параметрами потокових процесів ринку.

До нерівноважних станів товарного ринку може привести порушення принципу просторовочасового збалансування матеріального потоків, тобто маємо зв'язок між 7 та 8-ю класифікаційними ознаками (див. табл. 2). За географічними межами ринкового ланцюга доцільно виділити ЛР чотирьох типів. Логістичні «розриви» у ланцюгах локальних товарних ринків проявляються у формі обмеженості територіальних кордонів товароруху та незадоволеного 
споживчого попиту, регіональних ринків - як порушення зв'язків між провідними регіональними споживчими центрами й локальними територіями виробництва й розподілу продукції, державних ринків - як «обривання» відносин між розподільчими ланками різних рівнів (локального, регіонального, державного) в ієрархічній матеріалопровідній системі ринку. ЛР в ланцюгах глобальних ринків обумовлені, зокрема, високими технічними та інституційними бар'єрами входження національних виробників до глобальних ланцюгів вартості, неузгодженістю параметрів товаропотоків ринків двох рівнів. Слід відзначити низький ступінь інтегрованості українських товарних ринків до глобального. Так, за даними Світового банку, в Україні частка експорту, інтегрованого в глобальні ланцюги доданої вартості, досягла всього $5,7 \%$, тоді як в Польщі вона склала $27 \%$, Туреччині й Румунії - 38 \%, В’єтнамі - $59 \%$ [14].

В умовах інституційних трансформацій економічної системи, у т.ч. її логістичної складової, важливого значення набуває діагностика інституичійних «nасток», які учені визначають як «стійкі форми адаптації агентів ринку і населення до ірраціонального економічного середовища» [6, с.132]. Існуючі дослідження фокусуються на вивченні природи та типів «пасток» у системах. Ми в основу класифікації ЛР поклали ідею про причини виникнення «пасток» як зворотної реакції ЛЛТР на регуляторний вплив держави на потокові процеси за трьома головними напрямами державної політики: підтримка виробництва та експорту товарів з високою доданою вартістю, імпортозаміщення (див. табл. 2). В першому випадку можуть виникати ЛР внаслідок проблеми гнучкої адаптації сфери обслуговування руху продукції, що пройшла виробничу доробку, до зміни маршрутів, обсягів постачань тощо, а також обмежень виходу на споживчі ринки нових товарів. У другому випадку «розриви» пов'язані зі складнощами формування ефективних експортоорієнтованих ЛЛТР на засадах рівноправного входження вітчизняних суб'єктів у глобальні ланцюги вартості, які знаходять свій прояв у високих технічних бар'єрах для експорту товарів, невідповідності їх параметрів міжнародним стандар- там якості та екологічної безпеки, недостатності інвестицій для розбудови об'єктів логістичної інфраструктури тощо.

Державна політика імпортозаміщення є частиною імпортного протекціонізму, орієнтованого не на обмеження імпорту, а на стимулювання вітчизняного виробництва [15, с.73]. Негативною реакцією ЛЛТР на таку політику може бути зростання обсягів імпортних товаропотоків на фоні зменшення випуску вітчизняних товарів у ринкових ланцюгах внаслідок недостатньої фінансово-інформаційної підтримки політики імпортозаміщення та відсутності додаткових регуляторних заходів. Так, ЛР такого типу утворився в ланцюгах агропродовольчих ринків Білорусі, що пов'язано 3 масовим доступом на ринок більш конкурентоспроможних імпортних товарів, скороченням промислового й інноваційного потенціалу білоруських виробників харчової продукції, високою ресурсоємністю їх виробництв. Серед напрямів підвищення результативності політики імпортозаміщення чільне місце займають технічні заходи щодо підвищених вимог якості імпортної продукції, моніторинг цін, стимулювання виробників імпортозаміщених товарів [15, с.77].

На практиці для діагностики ЛР потокових процесів товарного ринку доцільно використати методи GAP-аналізу [11]. Шляхом експертного опитування фахівців-логістів та науковців у галузі макрологістичних систем ринку було проведено ранжування загального переліку параметрів потокових процесів товарного ринку. Перші 10 параметрів за ступенем їх значимості узагальнено в таблиці 3. 3 метою системної діагностики ЛР у ринкових ланцюгах експертами було вибрано 5 груп параметрів:

1) логістичні витрати (всього ланцюга та окремих ланок);

2) часові параметри (логістичної операції, циклу ланок та ланцюга);

3) додана вартість (ланцюгова та ланкова);

4) якість логістичного обслуговування в ринковому ланцюгу;

5) параметри сталого розвитку ланок ЛЛТР.

Таблиця 3

Ранжування логістичних «розривів» параметрів потокових процесів товарного ринку за ступенем їх значимості для ефективного функціонування ЛЛТР*

\begin{tabular}{|c|c|c|c|c|}
\hline Рейтинг & Параметри & $\begin{array}{c}\text { Умовні } \\
\text { позначення } \\
\end{array}$ & $\begin{array}{c}\text { Формули } \\
\text { розрахунку }\end{array}$ & Умовні позначення \\
\hline 1 & $\begin{array}{l}\text { Розрив у логістичних } \\
\text { витратах всього рин- } \\
\text { кового ланцюга }\end{array}$ & $\mathbf{G A P}_{\text {ЛВР }}$ & $\frac{\pi \mathrm{BP}_{\Phi}-Л \mathrm{BP}_{ц}}{\pi \mathrm{BP}}$ & $\begin{array}{l}\text { ЛВР } \\
\text { фактичні; } \\
\text { ЛВР }_{ц}-\text { ринкові логістичні витрати } \\
\text { цільові. }\end{array}$ \\
\hline 2 & $\begin{array}{l}\text { Розрив у логістичних } \\
\text { витратах певних ла- } \\
\text { нок ринкового лан- } \\
\text { цюга }\end{array}$ & $\mathbf{G A P}_{\text {ЛвЛ }}$ & $\frac{\text { ЛВ }_{\Phi}-л B Л_{ц}}{Л_{ц} Л_{ц}}$ & $\begin{array}{l}\text { ЛВЛ } \\
\text { фактичні; } \\
\text { ЛВР }_{ц}-\text { ланкові логістичні витрати } \\
\text { цільові. }\end{array}$ \\
\hline 3 & $\begin{array}{l}\text { Розрив у часі вико- } \\
\text { нання певної логісти- } \\
\text { чної операції }\end{array}$ & $\mathbf{G A P} \mathbf{P}_{\text {Тло }}$ & $\frac{\mathrm{TЛО}_{\Phi}-\text { ТЛО д }}{\text { ТЛО д }}$ & $\begin{array}{l}\text { ТЛО } \\
\text { логістичної операції; } \\
\text { ТЛО } \\
\text { операс виконання логістичної } \\
\text { оп договором. }\end{array}$ \\
\hline
\end{tabular}




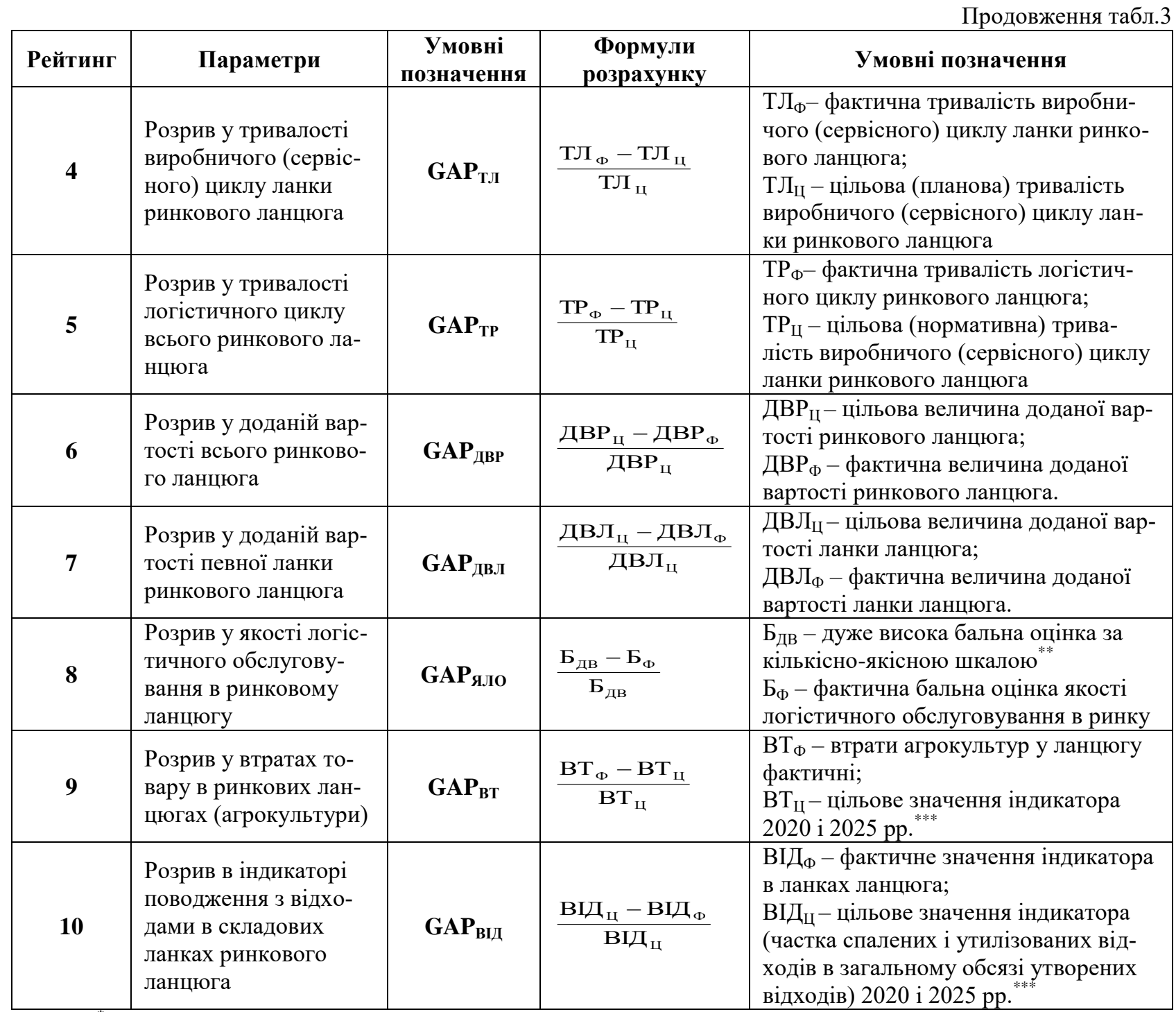

*Узагальнені дані експертного опитування;

** За даними джерела [16];

**** За даними джерела [17].

Слід зазначити, що параметр якості логістичного обслуговування структурується на загальні показники, притаманні всім товарним ринкам (наприклад, гнучкість ЛЛТР, надійність, безперебійність постачань сировини й товару, рівень використання інноваційних логістичних технологій та ін.) і специфічні, що відображають особливості процесів відтворення певних ринків [16, с.46]. Тобто ЛР можна визначити за кожним показником якості логістичного обслуговування; їх комплекс обгрунтовано в роботі [16].

Виокремлення параметрів сталого розвитку ланок ЛЛТР обумовлено необхідністю формування екологорієнтованих ринкових ланцюгів у відповідності до міжнародної парадигми сталого розвитку, що активно впроваджується в Україні. У даному напрямі експертами відібрано два показники, що мають логістичний вимір та пов'язані з реалізацією завдань Цілі сталого розвитку (далі - ЦСР) 12 «Відповідальне споживання та виробництво» [17, с.92]: (1) частка післязбиральних втрат агрокультур у їх загальному виробництві; (2) частка спалених і утилізованих відходів у загальному обсязі утворених відходів (загальна і в секторальному вимірі).

Для кількісної оцінки логістичних «розривів» параметрів потокових процесів ринку запропоновані показники, які розраховуються як частка різниці між цільовим (бажаним) і фактичним рівнем параметру та його цільовим значенням (див. табл. 3). Порівняння фактичних величин показників із граничними дозволяє встановити області виникнення ЛР у ринкових ланцюгах та провести їх системну діагностику, знайти та усунути причини «розривів». 3 використанням методу експертних оцінок було визначено граничні величини ЛР параметрів потокових процесів товарного ринку (таблиця 4). При цьому має місце така закономірність: чим вищий ступінь значимості показника для ефективного функціонування ринкового ланцюга, тим нижчий його граничний рівень. Найнижчий рівень GAP притаманний параметру ланцюгових логістичних витрат, найвищий - параметрам сталого розвитку ланок ЛЛТР. 
Таблиця 4

Граничні (мінімальні) величини параметрів потокових процесів товарного ринку, що свідчать про логістичні «розриви» в ланцюгах"

\begin{tabular}{|c|c|c|c|}
\hline Рейтинг & Параметри & $\begin{array}{c}\text { Умовні поз- } \\
\text { начення }\end{array}$ & $\begin{array}{c}\text { Мінімальний } \\
\text { рівень, пункти }\end{array}$ \\
\hline 1 & Розрив у логістичних витратах всього ринкового ланцюга & $\mathbf{G A P}_{\text {ЛВР }}$ & $\mathbf{0 , 0 5}$ \\
\hline 2 & $\begin{array}{l}\text { Розрив у логістичних витратах певних ланок ринкового лан- } \\
\text { цюга }\end{array}$ & $\mathbf{G A P}_{\text {ЛВЛ }}$ & $\mathbf{0 , 0 8}$ \\
\hline 3 & Розрив у часі виконання певної логістичної операції & $\mathbf{G A P}_{\text {Тло }}$ & $\mathbf{0 , 1 0}$ \\
\hline 4 & $\begin{array}{l}\text { Розрив у тривалості виробничого (сервісного) циклу ланки } \\
\text { ринкового ланцюга }\end{array}$ & $\mathbf{G A P}_{\text {Тл }}$ & $\mathbf{0 , 1 2}$ \\
\hline 5 & $\begin{array}{l}\text { Розрив у тривалості логістичного циклу всього ринкового } \\
\text { ланцюга }\end{array}$ & $\mathbf{G A P}_{\mathrm{TP}}$ & $\mathbf{0 , 1 3}$ \\
\hline 6 & Розрив у доданій вартості всього ринкового ланцюга & $\mathbf{G A P}_{\text {ДВP }}$ & $\mathbf{0 , 1 5}$ \\
\hline 7 & Розрив у доданій вартості певної ланки ринкового ланцюга & $\mathbf{G A P}_{\text {ДВЛ }}$ & $\mathbf{0 , 1 7}$ \\
\hline 8 & $\begin{array}{l}\text { Розрив у якості логістичного обслуговування в ринковому } \\
\text { ланцюгу }\end{array}$ & GАР яло & $\mathbf{0 , 1 9}$ \\
\hline 9 & Розрив у втратах товару в ринкових ланцюгах (агрокультури) & $\mathbf{G A P}_{\mathrm{BT}}$ & $\mathbf{0 , 2 0}$ \\
\hline 10 & $\begin{array}{l}\text { Розрив в індикаторі поводження з відходами в складових } \\
\text { ланках ринкового ланцюга }\end{array}$ & $\mathbf{G A P}_{\text {Від }}$ & 0,21 \\
\hline
\end{tabular}

*Узагальнені результати експертних оцінок

Для практичної апробації запропонованого методичного підходу до оцінки логістичних «розривів» потокових процесів у ЛЛТР (див. табл. 3) розрахуємо відхилення фактичних параметрів сталого розвитку ланок від цільових значень 2020 та 2025 pp., затверджених Міністерством економічного розвитку й торгівлі України в 2017 році [17, с.93]. Результати проведених авторами розрахунків представлено в таблиці 5.

Таблиця 5

GAP у фактичних і цільових значеннях параметрів сталої логістики в Україні у межах ЦСР 12 «Відповідальне споживання та виробництво»"

\begin{tabular}{|c|c|c|c|c|c|c|c|}
\hline \multirow{2}{*}{ Показники } & \multicolumn{6}{|c|}{ Роки } & \multirow{2}{*}{$\begin{array}{l}\text { ЦЗП } 2020 \text { p./ } \\
2025 \text { p.* }\end{array}$} \\
\hline & 2013 & 2014 & 2015 & 2016 & 2017 & 2018 & \\
\hline $\begin{array}{l}\text { 1. Післязбиральні втрати у загаль- } \\
\text { ному виробництві зернових куль- } \\
\text { тур, пункти }\end{array}$ & 0,024 & 0,025 & 0,023 & 0,020 & 0,018 & 0,018 & $\begin{array}{l}0,018 / \\
0,010\end{array}$ \\
\hline 1.1. $\mathrm{GAP}_{\text {ВТ }}$ (від ЦЗП 2020 р.) & 0,32 & 0,39 & 0,29 & 0,13 & 0,00 & $\mathbf{0 , 0 0}$ & $\mathrm{X}$ \\
\hline 1.2. $\mathrm{GAP}_{\text {ВТ }}$ (від ЦЗП 2025 р.) & 1,38 & 1,49 & 1,33 & 1,04 & 0,79 & $\mathbf{0 , 8 0}$ & $\mathrm{X}$ \\
\hline $\begin{array}{l}\text { 2. Післязбиральні втрати у загаль- } \\
\text { ному виробництві овочів та баш- } \\
\text { танних культур, пункти }\end{array}$ & 0,115 & 0,118 & 0,123 & 0,120 & 0,108 & 0,106 & $\mathbf{0 , 1 / 0 , 0 7}$ \\
\hline 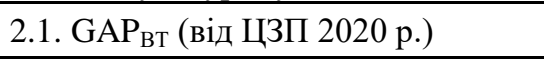 & 0,15 & 0,18 & 0,23 & 0,20 & 0,08 & 0,06 & $\mathrm{X}$ \\
\hline 2.2. $\mathrm{GAP}_{\text {ВТ }}$ (від ЦЗП 2025 р.) & 0,65 & 0,69 & 0,76 & 0,71 & 0,54 & 0,51 & $\bar{X}$ \\
\hline $\begin{array}{l}\text { 3. Спалені та утилізовані відходи у } \\
\text { загальному обсязі утворених від- } \\
\text { ходів, пункти }\end{array}$ & 0,3305 & 0,3105 & 0,300 & 0,290 & 0,2762 & 0,2971 & 0,35 / 0,45 \\
\hline 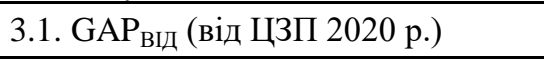 & 0,06 & 0,11 & 0,14 & 0,17 & 0,21 & $\mathbf{0 , 1 5}$ & $\mathrm{X}$ \\
\hline 3.1. GАР ВІд (від ЦЗП 2025 р.) & 0,27 & 0,31 & 0,33 & 0,36 & 0,39 & 0,34 & $\mathrm{X}$ \\
\hline
\end{tabular}

*Розраховано авторами за даними Державної служби статистики України [18];

** ЦЗП - Цільові значення показників 2020 та 2025 рр. за даними [17, с.93].

GAP у фактичних рівнях післязбиральних втрат агрокультур від цільових орієнтирів 2020 р. $\epsilon$ незначним (для зернових відсутній), значно нижчим граничного рівня $(0,20$ - див. табл. 4$)$. Ситуація змінюється в ході порівняльного аналізу 3 цільовими значеннями показників 2025 р.: «розрив» за даним показником в 2018 р. для зернових культур складає 0,8 пункти, овочевих i баштанних культур 0,51 пункти, що значно вище граничного рівня. 
За індикатором поводження з відходами спостерігається аналогічна ситуація, тобто допустима величина «розриву» при порівнянні з цільовим показником 2020 р. та істотний GAP при співставленні 3 цільовим орієнтиром 2025 р. (0,34 пункти, що вище граничного рівня в 0,21 пункти). Проведені розрахунки свідчать про нерівномірність руху України на шляху сталого розвитку, у т.ч. в логістичній сфері (див. табл. 5). GAP-аналіз дозволяє поглибити моніторинг ЦСР та відстежити найглибші розриви у параметрах сталого розвитку, своєчасно встановити та знівелювати причини ЛР.

Висновки та перспективи подальших досліджень. У ході дослідження обгрунтовано доцільність виокремлення спеціальних категорій («логістичний бар'єр», «вузьке місце» та «точка логістичних втрат») для диференціації проблемних областей товароруху за рівнями їх прояву в матеріалопровідній системі ринку, а саме: ланцюг - ланка - логістична операція. Запропоновано авторське визначення категорії «логістичний «розрив», що базується на теорії GAP-аналізу й відтворювальному підході, та акцентує увагу на причинах виникнення внутрішніх і зовнішніх «розривів» потокових процесів товарного ринку. Розроблено авторську класифікацію ЛР у ринкових ланцюгах за 9 ознаками, визначено їх природу та практичні прояви в ланцюгах агропродовольчих ринків України. Встановлено, що найбільш поширеним видом GAP у ЛЛТР є міжланкові «розриви», передусім комбіновані, які мають багатоаспектну типологію.

Запропоновано методичний підхід до діагностики ЛР, що передбачає ранжування «розривів» параметрів потокових процесів товарного ринку за ступенем їх значимості для ефективного функціонування ринкових ланцюгів за допомогою методу експертних оцінок. На основі проведеного ранжування встанов- лено найбільш значимі параметри, для яких визначено граничні величини «розривів». Слід відзначити можливість зміни та доповнення множини параметрів потокових процесів та їх граничних значень з урахуванням специфіки відтворювальних та логістичних процесів певних товарних ринків. На основі запропонованого методичного підходу визначено GAP у параметрах сталої логістики в Україні в площині ЦСР 12 «Відповідальне споживання й виробництво», встановлено нерівномірність досягнення ii завдань. У цілому перевищення граничних рівнів GAP $є$ аналітичним підгрунтям для проведення системної діагностики їх причин та обгрунтування адаптивних заходів щодо їх нівелювання в ЛЛТР.

Наукова новизна проведеного дослідження полягає в удосконаленні теоретико-методологічних засад ринкової логістики в частині обгрунтування теоретичних засад логістичних «розривів», їх природи та розширеної класифікації на сукупністю ознак, методичного підходу до діагностики ЛР потокових процесів товарного ринку. Прикладна значимість отриманих результатів дослідження визначається можливістю їх використання ринковими суб'єктами в ході ідентифікації ЛР в ланцюгах, їх ранжування та системної діагностики, а також органами влади різних рівнів в ході визначення GAP найбільш значимих параметрів потокових процесів стратегічних товарних ринків, як аналітичне підгрунтя для розробки механізмів і заходів подолання глибинних ЛР у ринкових ланцюгах для підвищення їх ефективності функціонування та сталого розвитку. Використання теоретико-методичних засад ЛР для дослідження та оцінки GAP у ланцюгах різних товарних ринків України формує перспективи подальших розробок у даному напрямі.

\section{Література}

1. Брынцев А.Н. Фрагментация и барьеры в логистике. М.: Экономика и жизнь, 2011. 250 с.

2. Синько А.В., Брынцев А.Н. Особенности фрагментации и барьеров логистики в условиях свободной экономической зоны // Российское предпринимательство. 2012. Т. 13. № 7. С. 64-69.

3. Вірозуб О.Д. Особливості матеріального потоку у складі логістичної системи в агросекторі // Таврійський науковий вісник. 2015. № 90. С.196-202.

4. Грейз Г.М., Кузменко Ю.Г., Марковский В.А. Совершенствование методов исследования цепей поставок на основе GAP-анализа // Вестник ЮУрГУ. Сер. Экономика и менеджмент. 2013. Т.7. №1. С.161-164.

5. Курант Т.І. Виявлення інформаційного розриву у взаємовідносинах споживача і виробника у логістичних мережах // Глобальні та національні проблеми економіки. 2014. №2. С.98-101.

6. Точилін В.В., Осташко Т.О., Пустовойт О.В. та ін. Ринки реального сектора економіки України: структурно-інституційний аналіз: монографія / за ред.. В.О. Точиліна. Київ: ІЕП НАН України, 2009. 640 с.

7. Плышевский Б.А. Деформации против модернизации // Экономист. 2011. №5. С.3-17.

8. Шинкарук Л.В. Структурний і соціальний аспекти оцінки пропорційності та диспропорційності в економіці // Економічний вісник. 2014. №4. С.71-78.

9. Економічна енциклопедія / відп. ред. С.В. Мочерний. Т.І. Київ: Видавничий центр «Академія», 2000. $863 \mathrm{c}$.

10. Економічний словник-довідник. URL: https://subject.com.ua/economic/dict/250.html (дата звернення 11.11.2020).

11. Franklin M. Performance Gap Analysis. Infoline ASTD, 2006.

12. Методологічні засади формування ефективної логістики товарних ринків: монографія / за ред. Буркинського Б.В., Нікішиної О.В. Одеса: ІПРЕЕД НАНУ, 2020. 200с. 
13. Буркинський Б.В., Нікішина О.В. Принципи формування ефективних логістичних ланцюгів товарних ринків: монографія. Одеса : ІПРЕЕД НАНУ, 2019. 85с.

14. Ukraine. Special focus note on trade. Tapping Ukraine's trade potential. URL: http://pubdocs.worldbank.org/en/455251538644632238/Ukraine-Special-Focus-Note-Oct-2018-ENG.pdf (дата звернення 11.10.2020).

15. Валевич Р.П., Свиренко Н.Е. Политика испортозамещения: нове подходы к формированию и реализации // Научные труды Белорусского государственного экономического университета. 2019. №1. С.72-79.

16. Буркинський Б.В., Нікішина О.В. Діагностика ефективності логістичних ланцюгів товарних ринків: наук. доповідь. Одеса: Одеса: ІПРЕЕД НАН України, 2020. 75 с.

17. Цілі Сталого Розвитку: Україна: Національна доповідь 2017. Київ: Міністерство економічного розвитку і торгівлі України, 2017. 176 с.

18. Офіційний сайт Державної служби статистики України. URL: http://www.ukrstat.gov.ua/ (дата звернення 11.10.2020).

Стаття надійшла 2.11.2020

Стаття прийнята до друку 16.11.2020

Доступно в мережі Internet 29.12.2020

\author{
Никишина О.В. \\ доктор экономических наук, старший научный сотрудник, \\ начальник отдела рыночных механизмов и структур \\ E-mail: ksenkych@gmail.com. \\ ORCID ID: 0000-0002-7172-3551 \\ Тараканов Н.Л. \\ кандидат экономических наук, старший научный сотрудник \\ отдел рыночных механизмов и структур \\ Институт проблем рынка и экономико- \\ экологических исследований НАН Украины \\ Французский бульвар, 29, г. Одесса, Украина, 65044 \\ E-mail: tarakanovnikolajleonidovic@gmail.com \\ ORCID ID: 0000-0002-3827-237
}

\title{
ТЕОРЕТИКО-МЕТОДИЧЕСКИЕ ОСНОВЫ ЛОГИСТИЧЕСКИХ «РАЗРЫВОВ» В ЦЕПЯХ ТОВАРНЫХ РЫНКОВ
}

Статья посвящена обоснованию теоретико-методического обеспечения для идентификации и диагностики логистических «разрывов» потоковых процессов в цепях товарных рынков на основе воспроизводственного подхода и GAP-анализа. В ходе исследования обоснована целесообразность использования специальных категорий («логистический барьер», «узкое место» и «точка логистических потерь») для дифференциации проблемных областей товародвижения по уровням их проявления в макрологистической системе: цепь - звено - логистическая операция. Предложено авторское определение категории «логистический «разрыв», а именно: расхождение между фактическими и целевыми значениями параметров потоковых процессов вследствие нарушения оптимальных соотношений между элементами рыночного цепи, ослабление (отсутствии) связей и взаимодействий между ее звеньями, что не обеспечивает расширенное воспроизводство товародвижения и оптимизацию общей рыночной добавленной стоимости. Акцентировано внимание на причинах возникновения «разрывов» потоковых процессов товарного рынка во внутреннем и внешнем измерении.

Разработана расширенная классификация логистических «разрывов» в рыночных цепях по 9 признаками: (1) месту возникновения в релевантной цепи; (2) видам потоковых процессов; (3) глубине воздействия на функционирование рыночной цепи; (4) причинам возникновения; (5) структуре цепи; (6) фрормам связей между звеньями; (7) соотношению спроса и предложения; (8) географическим пределам цепей; (9) адаптации рыночных цепей к мероприятиям государственной поддержки товародвижения. Определены природа и особенности «разрывов» различных видов, формы их проявления в цепях агропродовольственных рынков Украины. Установлено, что наиболее распространенным видом GAP в цепях товарных рынков являются межзвеньевые «разрывы», прежде всего комбинированные, которые имеют многоаспектную типологию.

Предложен методический подход к диагностике GAP, предусматривающий ранжирование «разрывов» параметров потоковых процессов товарного рынка по степени их значимости для эффективного функционирования рыночных цепей и определение предельных величин «разрывов» с помощью метода экспертных оценок. На основе предложенного методического подхода определен GAP в параметрах 
устойчивой логистики в Украине, установлена неравномерность достижения задач Цели устойчивого развития 12 «Ответственное потребление и производство». Отмечено, что превышение предельных уровней GAP является аналитической базой для проведения системной диагностики их причин и обоснования механизмов и мер их нивелирования с учетом специфики «разрыва» и типа рыночной цепи.

Ключевые слова: логистический «разрыв», цепь товарного рынка, звено, потоковые процессы, параметры, диагностика логистических «разрывов».

\author{
Nikishyna 0. \\ Doctor of Economics, Senior Researcher \\ Head of Department of Market Mechanisms and Structures \\ E-mail: ksenkych@gmail.com \\ ORCID ID: 0000-0002-7172-3551 \\ Tarakanov M. \\ $\mathrm{PhD}$, Senior Researcher \\ of Department of market mechanisms and structures \\ Institute of Market Problems and Economic \& Ecological Research \\ of National Academy of Sciences of Ukraine \\ Frantsuzskiy boulevard, 29, Odesa, Ukraine, 65044 \\ E-mail: tarakanovnikolajleonidovic@gmail.com \\ ORCID ID: 0000-0002-3827-237
}

\title{
THEORETICAL AND METHODICAL BASES OF LOGISTIC «GAPS» IN THE CHAINS OF COMMODITY MARKETS
}

The article is devoted to the substantiation of theoretical and methodical support for the identification and diagnosis of logistic «gaps» of flow processes in the chains of commodity markets on the basis of a reproducible approach and GAP-analysis. The study substantiates the feasibility of using special categories («logistic barrier», «bottleneck» and «point of logistic losses») to differentiate problem areas of logistics at the levels of their manifestation in the macrologistics system: chain - link - logistic operation. The author's definition of the category «logistic «gap» has been proposed, namely: the discrepancy between the actual and target values of the parameters of flow processes due to violation of optimal relationships between elements of the market chain, weakening (absence) of links and interactions between its links, which does not provide expanded reproduction of logistics and optimization of overall market value added. Emphasis is placed on the causes of «gaps» in the flow processes of the commodity market in the internal and external dimensions.

An extended classification of logistic "gaps» in market chains has been developed by 9 features: (1) place of origin in the relevant chain; (2) types of flow processes; (3) the depth of influence on the functioning of the market chain; (4) causes; (5) chain structure; (6) forms of connections between links; (7) the ratio of supply and demand; (8) the geographical boundaries of the chains; (9) adaptation of market chains to measures of state support of logistics. The nature and features of «gaps» of different types, forms of their manifestation in the chains of agri-food markets of Ukraine have been determined. It has been established that the most common type of GAP in the chains of commodity markets are interlink «gaps», primarily combined, ones, which have a multifaceted typology.

A methodical approach to GAP diagnostics has been proposed, which provides for ranking «gaps» in the parameters of flow processes of the commodity market according to the degree of their importance for the effective functioning of market chains and determining the limits of «gaps» using the method of expert assessments. Based on the proposed methodological approach, GAP has been defined in the parameters of sustainable logistics in Ukraine, the unevenness of achieving the objectives of the Sustainable Development Goal 12 «Responsible consumption and production» has been established. It has been emphasized that exceeding the GAP limit levels is an analytical basis for a systematic diagnosis of their causes and justification of mechanisms and measures for their leveling, taking into account the specifics of the "gap» and the type of market chain.

Key words: logistic «gap», commodity market chain, link, flow processes, parameters, diagnostics of logistic «gaps».

\section{References}

1. Bryintsev, A. (2011). Fragmentatsiya i bareryi v logistike. Moscow: Ekonomika i zhizn.

2. Sinko, A., \& Bryintsev, A. (2012). Osobennosti fragmentatsii i barerov logistiki v usloviyah svobodnoy ekonomicheskoy zonyi. Rossiyskoe predprinimatelstvo, 13(7), 64-69. 
3. Virozub, O. (2015). Osoblyvosti materialnoho potoku u skladi lohistychnoi systemy v ahrosektori. Tavriiskyi naukovyi visnyk, (90), 196-202.

4. Greyz, G., Kuzmenko, Yu., \& Markovskiy, V. (2013). Sovershenstvovanie metodov issledovaniya tsepey postavok na osnove GAP-analiza. Vestnik $Y u U r G U, 7(1), 161-164$.

5. Kurant, T. (2014). Vyiavlennia informatsiinoho rozryvu u vzaiemovidnosynakh spozhyvacha i vyrobnyka u lohistychnykh merezhakh. Hlobalni ta natsionalni problemy ekonomiky, (2), 98-101.

6. Tochylin, V., Ostashko, T., \& Pustovoit, O. (2009). Rynky realnoho sektora ekonomiky Ukrainy: strukturnoinstytutsiinyi analiz. (V. Tochylina, Ed.). Kyiv: IEP NAN Ukrainy.

7. Plyishevskiy, B. (2011). Deformatsii protiv modernizatsii. Ekonomist, (5), 3-17.

8. Shynkaruk, L. (2014). Strukturnyi i sotsialnyi aspekty otsinky proportsiinosti ta dysproportsiinosti V ekonomitsi. Ekonomichnyi visnyk, (4), 71-78.

9. Mochernyi, S. (Ed.). (2000). Ekonomichna entsyklopediia. Kyiv: Vydavnychyi tsentr «Akademiia».

10. Ekonomichnyi slovnyk-dovidnyk. Retrieved October 11, 2020, from https://subject.com.ua/economic/dict/250.html

11. Franklin, M. (2006). Performance Gap Analysis. Infoline ASTD.

12. Burkynskyi, B., \& Nikishyna, O. (Eds.). (2020). Metodolohichni zasady formuvannia efektyvnoi lohistyky tovarnykh rynkiv. Odesa: IPREED NANU.

13. Burkynskyi, B., \& Nikishyna, O. (2019). Pryntsypy formuvannia efektyvnykh lohistychnykh lantsiuhiv tovarnykh rynkiv. Odesa: IPREED NANU.

14. Ukraine. Special focus note on trade. Tapping Ukraine's trade potential. (2018). Retrieved October 11, 2020, from http://pubdocs.worldbank.org/en/455251538644632238/Ukraine-Special-Focus-Note-Oct-2018-ENG.pdf

15. Valevich, R., \& Svirenko, N. (2019). Politika isportozamescheniya: nove podhodyi k formirovaniyu i realizatsii. Nauchnyie trudyi Belorusskogo gosudarstvennogo ekonomicheskogo universiteta, (1), 72-79.

16. Burkynskyi, B., \& Nikishyna, O. (2020). Diahnostyka efektyvnosti lohistychnykh lantsiuhiv tovarnykh rynkiv. Odesa: IPREED NAN Ukrainy.

17. Tsili Staloho Rozvytku. (2017). Kyiv: Ministerstvo ekonomichnoho rozvytku i torhivli Ukrainy.

18. Ofitsiinyi sait Derzhavnoi sluzhby statystyky Ukrainy. Retrieved October 11, 2020, from http://www.ukrstat.gov.ua/

Received 2 November 2020 Approved 16 November 2020 Available in Internet 29.12.2020

Цитування згідно ДСТУ 8302:2015

Нікішина О. В., Тараканов М.Л. Теоретико-методичні засади логістичних «розривів» у ланцюгах товарних ринків // Економіка харчової промисловості. 2020. Т.12, вип. 4. С. 3-16. doi: 10.15673/fie.v12i4.1906

Cite as APA style citation

Nikishyna, O., \& Tarakanov, M. (2020). Theoretical and methodical bases of logistic «gaps» in the chains of commodity markets. Food Industry Economics, 12(4), 3-16. doi: 10.15673/fie.v12i4.1906 